\title{
ADDITIONAL RECORDS OF LOBOTES SURINAMENSIS, CARANX CRYSOS, ENCHELYCORE ANATINA, AND LAGOCEPHALUS SCELERATUS (ACTINOPTERYGII) IN THE ADRIATIC SEA
}

\author{
Jakov DULČIĆ ${ }^{1 *}$, Branko DRAGIČEVIĆ ${ }^{1}$, Nenad ANTOLOVIĆ ${ }^{2}$, Jadranka SULIĆ-ŠPREM ${ }^{3}$, \\ Valter KOŽUL ${ }^{2}$, and Robert GRGIČEVIĆ ${ }^{1}$ \\ ${ }^{1}$ Institute of Oceanography and Fisheries, Split, Croatia \\ ${ }^{2}$ University of Dubrovnik, Institute for Marine and Coastal Research, Dubrovnik, Croatia \\ ${ }^{3}$ Dubrovnik Natural History Museum, Dubrovnik, Croatia
}

Dulčić J., Dragičević B., Antolović N., Sulić-Šprem J., Kožul V., Grgičević R. 2014. Additional records of Lobotes surinamensis, Caranx crysos, Enchelycore anatina, and Lagocephalus sceleratus (Actinopterygii) in the Adriatic Sea. Acta Ichthyol. Piscat. 44 (1): 71-74.

\begin{abstract}
Additional records of four fish species from the Adriatic Sea are reported: Atlantic tripletail, Lobotes surinamensis (Bloch, 1790) (Perciformes: Lobotidae); blue runner, Caranx crysos (Mitchill, 1815) (Perciformes: Carangidae); fangtooth moray, Enchelycore anatina (Lowe, 1838) (Anguilliformes: Muraenidae); and silvercheeked toadfish, Lagocephalus sceleratus (Gmelin, 1789) (Tetraodontiformes: Tetraodontidae). More evidence is needed to indicate establishment of populations of these species in the Adriatic Sea. Lessepsian migrant Lagocephalus sceleratus is the third Lessepsian fish species from the Adriatic Sea with more than one record.
\end{abstract}

Keywords: non-indigenous, alien species, tropicalization, Lessepsian migration

The Mediterranean basin is considered a major recipient of non-indigenous marine species. Their number is estimated to range from 573 species (Galil 2009) to 986 species, of which 249 are associated with the Central Mediterranean region (Zenetos et al. 2012). According to Zenetos et al. (2010), 149 non-indigenous fish species have been recorded from the Mediterranean Sea. Of this number, approximately 80 species are Lessepsian fish migrants (Golani et al. 2011). In the Adriatic Sea, at least 24 nonindigenous fish species have been reported in the last two decades of which 13 are Lessepsian migrants (Dulčić and Dragičević 2011). Recently, two species of Atlantic origin, the queen angelfish, Holacanthus ciliaris (Linnaeus, 1758), and the creole-fish, Paranthias furcifer (Valenciennes, 1828), have been anthropogenically introduced to the Adriatic Sea (Dulčić and Dragičević 2013a, 2013b). Additionally, there are cases of shipping- and aquaculture-related introductions such as the cases of dwarf flathead, Elates ransonnettii (Steindachner, 1876), and red seabream, Pagrus major Temminck et Schlegel, 1843, respectively (Dulčić and Kraljević 2007, Dulčić et al. 2010).

Golani et al. (2011) emphasized that it is important that first records of alien fish species in new areas are followed by reports of subsequent records and that such addi- tional records are needed to acknowledge the establishment and distribution in the new habitat. Subsequent records may indicate that previous occurrences were not just accidental and that the new region is included in the zoographic range of the species (Golani and Levy 2005). The aim of the present work is to report subsequent records of fishes which have only recently been recorded in the Adriatic Sea for the first time. In this paper we report subsequent records of the Atlantic tripletail, Lobotes surinamensis (Bloch, 1790) (Perciformes: Lobotidae); blue runner, Caranx crysos (Mitchill, 1815) (Perciformes: Carangidae); fangtooth moray, Enchelycore anatina (Lowe, 1838) (Anguilliformes: Muraenidae); and silvercheeked toadfish, Lagocephalus sceleratus (Gmelin, 1789) (Tetraodontiformes: Tetraodontidae). Specimens of Caranx crysos and Lagocephalus sceleratus were caught by trammel net, while those of Lobotes surinamensis by seine net. The photograph of Enchelycore anatina and detailed information on it were obtained from Mr. Rok Korošec from the Feel Deep Diving Club, Slovenia. Photographs of Caranx crysos were obtained from the fisherman Mićo Kočović who caught it and determination of the species was based on them. The specimen of Lobotes surinamensis was deposited in the collection of

\footnotetext{
* Correspondence: Dr. sc. Jakov Dulčić, Institut za oceanografiju i ribarstvo, Šetalište I. Meštrovića 63, 21000 Split, Croatia, phone: (+385) 21408013, e-mail: (JD) dulcic@izor.hr, (BD) brankod@izor.hr, (NA) nenad.antolovic@unidu.hr, (JSS) jadranka.sulic@gmail.com, (VK) valter.kozul@unidu.hr, (RG)robertg@izor.hr.
} 
the Institute for Marine and Coastal Research in Dubrovnik, Croatia, while of Lagocephalus sceleratus in the Ichthyological collection of the Institute of Oceanography and Fisheries in Split, Croatia.

\section{LOBOTIDAE}

Lobotes surinamensis (Bloch, 1790)

Material examined. One ô specimen, $\mathrm{TL}=390 \mathrm{~mm}$, $W=1400 \mathrm{~g}, 5$ December 2011, from Mali Ston Bay $\left(42^{\circ} 52^{\prime} 30^{\prime \prime} \mathrm{N}\right.$; 17 $\left.37^{\prime} 30^{\prime \prime} \mathrm{E}\right)$ (southern Adriatic Sea, Croatia) (Fig. 1).

Short description. Deep oval-shaped and compressed body with concave upper head profile and relatively small eyes. Mouth oblique and semi-superior, lower jaw slightly protruding. Posterior portions of dorsal and anal rays rounded and opposite to each other. Body colour grey brownish with irregularly shaped larger darker blotches. Posterior margins of dorsal, anal, and caudal fin darker.

Remarks. Atlantic tripletail, L. surinamensis, is a cosmopolitan species found in tropical and subtropical waters of all oceans (Tortonese 1990). Prior to this record, it was recorded once in the middle Adriatic on 21 June 2010 (5 NM SW from Biševo Island, Croatia) $(\mathrm{TL}=380 \mathrm{~mm}$, $W=1500 \mathrm{~g}$ ) (Fig. 1) (Dulčić and Dragičević 2011). Findings of L. surinamensis in the Adriatic Sea are probably a consequence of increased abundance of this species in the southern Mediterranean waters amplified by the changes in hydrological conditions in the area. It seems that this species recently established its population in the area of Maltese islands which is indicated by the presence of juveniles in the area (Deidun et al. 2010).

\section{CARANGIDAE}

Caranx crysos (Mitchill, 1815)

Material examined. Photo of a specimen (245 mm TL), according to the fisherman, 4 other specimens were collected but no additional data or photograph were provided, 1 March 2013, Ulcinj (Montenegro coast, southern Adriatic) (Figs. 1 and 2).

Short description. (Based on photos provided by the fisherman who caught it.) Body compressed and elongated, moderately deep. Snout pointed and terminate. Lateral line arched anteriorly, above pectoral fin. Caudal fin forked, pectoral fins long and falcate. End of upper jaw reaching under mid-eye. Body colour silverish, black spot visible on upper posterior edge of operculum.

Remarks. Blue runner, Caranx crysos, is distributed in the eastern Atlantic from Senegal to Angola, including the western Mediterranean, St. Paul's Rock, and Ascension Island. It has also been reported from Mauritania and the western Atlantic from Nova Scotia in Canada to Brazil, including the Gulf of Mexico and the Caribbean. Fischer et al. (1987) reported its presence in the entire Mediterranean except for the Adriatic Sea and the coasts of Turkey. Prior to the presently reported finding, one specimen was recorded in the Northern Adriatic (western coast of Istra Peninsula, Croatia) (TL $=368 \mathrm{~mm}, W=634 \mathrm{~g}$ ) (Fig. 1) on 27 August 2008 (Dulčić et al. 2009). The find- ing of additional specimens in the Adriatic Sea (southern Adriatic) suggests that this species extended its distribution in the Adriatic Sea. This is the first record of C. crysos from Montenegrin coast.

\section{MURAENIDAE}

Enchelycore anatina (Lowe, 1839)

Material examined. Photo of a specimen (Fig. 3); 22 September 2011, from Bijelac Islet near Lastovo Island (middle Adriatic, Croatian coast) (Figs. 1 and 3).

Short description. (Determination of the specimen was based on a single photograph. However, important diagnostic features were clearly visible and these are): Pointed head with a distinctly elevated occipital region, tubular anterior nostril, posterior nostril round to oval opening in front of eye, large mouth, with cleft extending well back behind eye, arched jaw, with many conical and sharp fanglike teeth, light brown snout and cheeks with yellow dots.

Remarks. The fangtooth moray, Enchelycore anatina, is a tropical Atlantic species distributed in the eastern Atlantic from St. Helena Island to the Azores (Golani et al. 2002). It is also recorded in the Mediterranean Sea (Ben-Tuvia and Golani 1984, Kalogirou 2010). Prior to

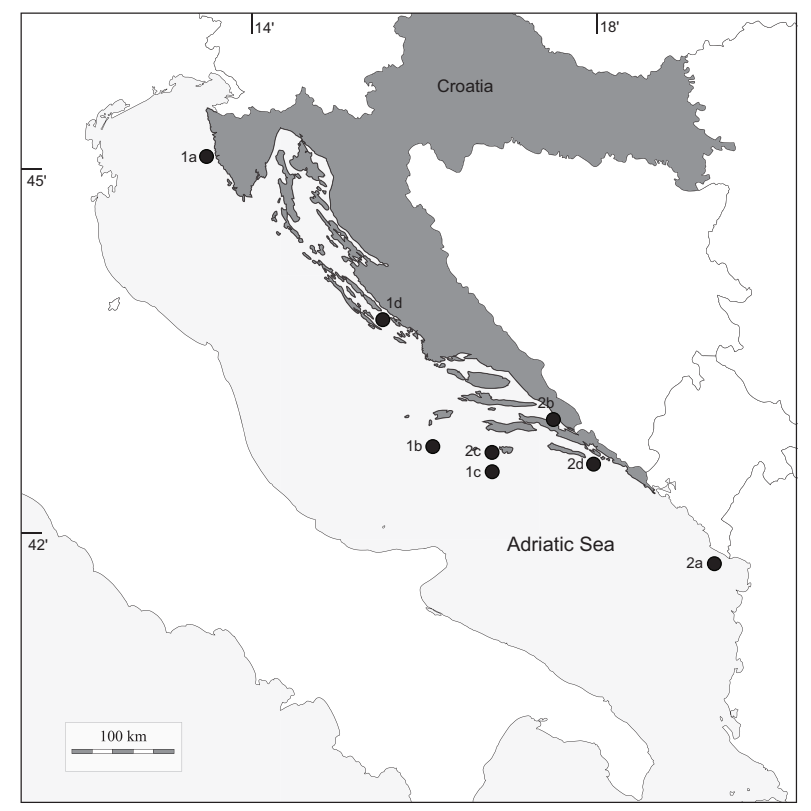

Fig. 1. Locations of first and additional records of Caranx crysos (a), Lobotes surinamensis (b), Enchelycore anatina (c), and Lagocephalus sceleratus (d)

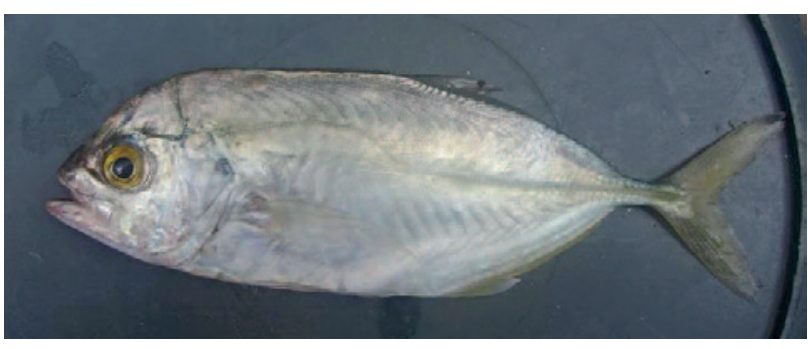

Fig. 2. Specimen of blue runner, Caranx crysos, caught near Ulcinj, Montenegro (photo used with permission of Mr. Mićo Kočović) 


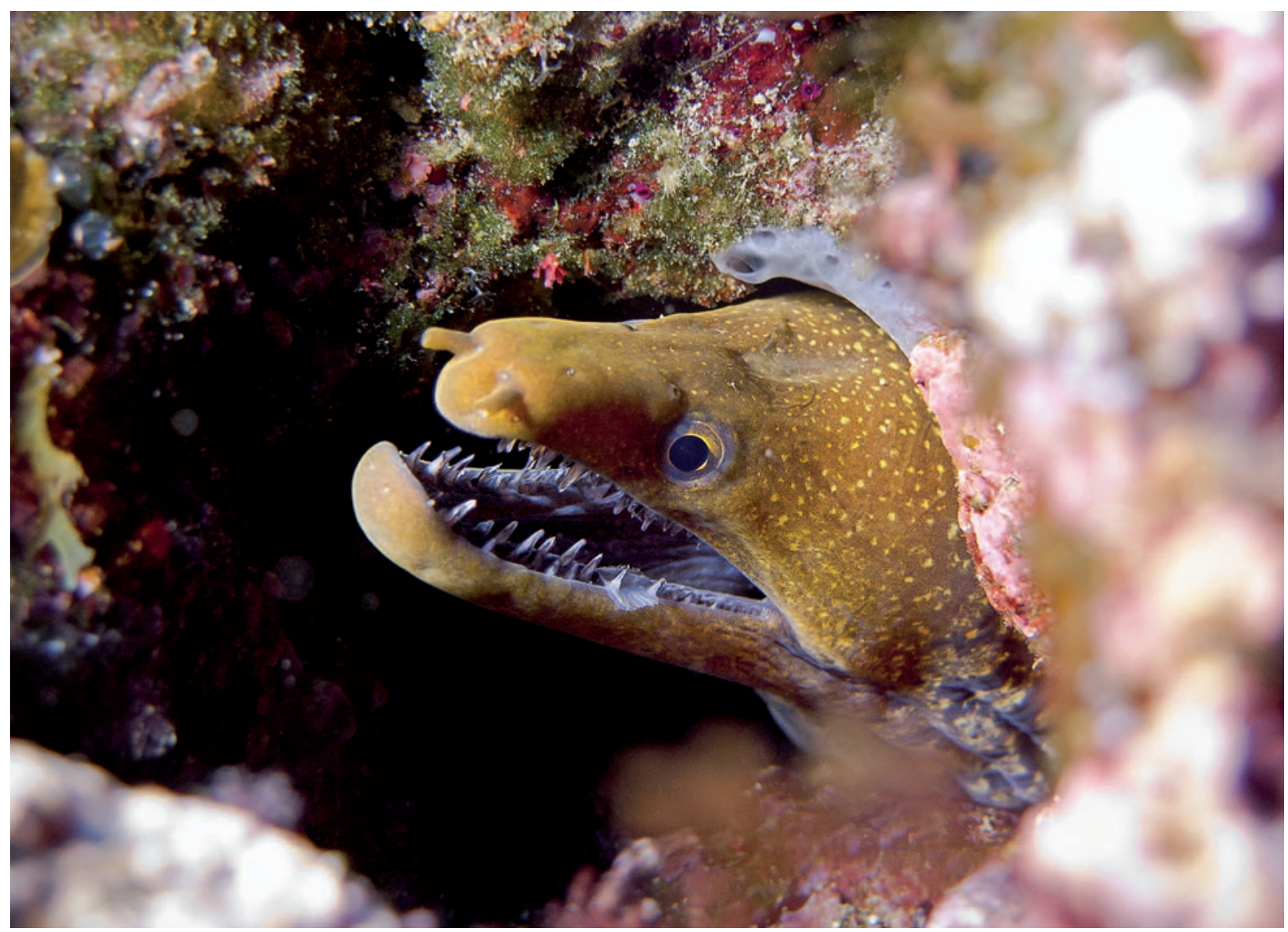

Fig. 3. Specimen of fangtooth moray, Enchelycore anatina, sighted near island Lastovo, Croatia (Photo: Rok Korošec)

this finding, two specimens were observed (and determined from the photographs) in July of 2010 near Sušac Island, Croatia (Lipej et al. 2011). It is suggested that this species is an overlooked inhabitant of the Mediterranean rather than a recent colonizer (Kalogirou 2010). This hypothesis could also be applied to the Adriatic case.

\section{TETRAODONTIDAE}

Lagocephalus sceleratus (Gmelin, 1789)

Material examined. Specimen: LS-18313-IOR, TL= $492 \mathrm{~mm}$; $W=1422$ g, 17 March 2013, Tribunj (middle eastern Adriatic, Croatian coast) (Fig. 1).

Short description. Body elongated, cylindrical, and robust. Dorsal and anal fins with short base and situated opposite to each other, pectoral fins broad and relatively short. Small spinules present in dorsal and ventral area. Greyish-green colour dorsally with black spots, two silver bands extending from mouth to caudal fin on lateral side; ventral side of body white, silver blotch present in front of eyes.

Remarks. Lessepsian migrant-silver-cheeked toadfish, Lagocephalus sceleratus - is distributed in the tropical Indian and Pacific Oceans, from where it originates (Smith and Heemstra 1986). In the Mediterranean Sea this species was first recorded in 2003 on the south-eastern Aegean Sea coast of Turkey (Akyol et al. 2005). First specimen of L. sceleratus in the Adriatic Sea was caught in October 2012 on the northern side of Jakljan Island
(Croatia, southern Adriatic). It was a sexually mature female $(\mathrm{TL}=66.3 \mathrm{~cm}$ ) weighing $3.531 \mathrm{~kg}$ (Jadranka Sulić-Šprem, personal communication). The finding of additional specimen in the mid-eastern Adriatic (Fig. 2) in less than one year from its previous record suggests that this species extended its distribution to the Adriatic Sea.

\section{ACKNOWLEDGEMENTS}

We would like to thank Mr. Rok Korošec, Mr. Tomas Robič, Mr. Lovre and Mr. Filip Bolanča, Mr. Pero Ugarković and Mr. Mićo Kočović for providing the specimens and photos of the specimens. This work was supported by project 001-0013077-0844 financed by Ministry of Science, Education and Sports of Republic of Croatia.

\section{REFERENCES}

Akyol O., Ünal V., Ceyhan T., Bilecenoglu M. 2005. First confirmed record of Lagocephalus sceleratus (Gmelin, 1789), in the Mediterranean Sea. Journal of Fish Biology 66 (4): 1183-1186. DOI: 10.1111/j.0022-1112.2005.00667.x

Ben-Tuvia A., Golani D. 1984. A West African fangtooth moray eel Enchelycore anatina from the Mediterranean coast of Israel. Copeia 1984 (2) 541-544. DOI: 10.2307/1445214

Deidun A., Vella P., Sciberras A., Sammut R. 2010. New records of Lobotes surinamensis (Bloch, 1790) in Maltese coastal waters. Aquatic Invasions 5 (Suppl. 1): S113-S116. DOI: 10.3391/ai.2010.5.S1.023 
Dulčić J., Dragičević B. 2011. First record of the Atlantic tripletail, Lobotes surinamensis (Bloch, 1790), in the Adriatic Sea. Journal of Applied Ichthyology 27 (6): 1385-1386. DOI: 10.1111/j.1439-0426.2011.01808.x

Dulčić J., Dragičević B. 2013a. Paranthias furcifer (Perciformes: Serranidae), a new alien fish in the Mediterranean Sea. Journal of Fish Biology 82 (1): 332-337. DOI: $10.1111 / \mathrm{j} .1095-8649.2012 .03462 . x$

Dulčić J., Dragičević B. 2013b. Holacanthus ciliaris (Linnaeus, 1758) (Teleostei: Pomacanthidae), first record from the Mediterranean Sea. Journal of Applied Ichthyology 29 (2): 465-467. DOI: 10.1111/jai.12096

Dulčić J., Kraljević M. 2007. On the record of red seabream Pagrus major (Temminck and Schlegel, 1843) (Osteichthyes: Sparidae) in the Adriatic Sea. Scientia Marina 71 (1): 15-17.

Dulčić J., Pallaoro A., Dragičević B. 2009. First record of the blue runner, Caranx crysos (Mitchill, 1815), in the Adriatic Sea. Journal of Applied Ichthyology 25 (4): 481-462. DOI: $10.1111 / j .1439-0426.2009 .01243 . x$

Dulčić J., Pallaoro A., Dragičević B., Stagličić-Radica N. 2010. First record of dwarf flathead Elates ransonnetii [sic] (Platycephalidae) in the Adriatic Sea. Cybium 34 (2): 222-223.

Fischer W., Schneider M., Bauchot M.-L. 1987. Fiches d'identification des espèces pour les Besoins de la Pêche. Méditerranée et Mer Noire. Zone de pêche 37. Vol. 2., FAOCEE, Rome.

Galil B.S. 2009. Taking stock: inventory of alien species in the Mediterranean Sea. Biological Invasions 11 (2): 359-372. DOI: 10.1007/s10530-008-9253-y

Golani D., Levy Y. 2005. New records and rare occurrences of fish species from the Mediterranean coast of Israel. Zoology in the Middle East 36 (1): 27-32. DOI: 10.1080/ 09397140.2005.10638124

Golani D., Orsi-Relini L., Massuti E., Quignard, J.P. 2002. CIESM Atlas of exotic species in the Mediterranean. CIESM Publishers, Monaco.

Golani D., Sonin O., Edelist D. 2011 Second records of the Lessepsian fish migrants Priacanthus sagittarius and Platax teira and distribution extension of Tylerius spinosissimus in the Mediterranean. Aquatic Invasions 6 (Suppl. 1): S7-S11. DOI: 10.3391/ai.2011.6.S1.002
Kalogirou S. 2010. First record of the non-indigenous fangtooth moray Enchelycore anatina from Rhodes Island, south-eastern Aegean Sea. Mediterranean Marine Science 11 (2): 357-360. DOI: $10.12681 / \mathrm{mms} .83$

Lipej L., Furlan B., Antolović N., Golani D., Dulčić J. 2011. The first record of fangtooth moray, Enchelycore anatina (Lowe, 1839), in the Adriatic Sea. Journal of Applied Ichthyology 27 (6): 1387-1389. DOI: 10.1111/j.14390426.2011.01816.x

Smith M.M., Heemstra P.C. 1986. Tetraodontidae. 894-903. In: Smith M.M., Heemstra P.C. (eds.) Smiths' sea fishes. Springer-Verlag, Berlin, Germany.

Tortonese E. 1990. Lobotidae. p. 780. In: Quero J.C., Hureau J.C., Karrer C., Post A., Saldanha L. (eds.) Check-list of the fishes of the eastern tropical Atlantic (CLOFETA). Vol. 2. JNICT, Lisbon; SEI, Paris; and UNESCO, Paris.

Zenetos A., Gofas S., Morri C., Rosso A., Violanti D., García Raso J.E., Çinar M.E., Almogi-Labin A., Ates A.S., Azzurro E., Ballesteros E., Bianchi C.N., Bilecenoglu M., Gambi M.C., Giangrande A., Gravili C., Hyams-Kaphzan O., Karachle P.K., Katsanevakis S., Lipej L., Mastrototaro F., Mineur F., Pancucci-Papadopoulou M.A., Ramos Esplá A., Salas C., San Martín G., Sfriso A., Streftaris N., Verlaque M. 2012. Alien species in the Mediterranean Sea by 2012. A contribution to the application of European Union's Marine Strategy Framework Directive (MSFD). Part 2. Introduction trends and pathways. Mediterranean Marine Science 13 (2): 328-35. DOI: 10.12681/mms.327

Zenetos A., Gofas S., Verlaque M., Çinar M.E., García Raso J.E., Bianchi C.N., Morri C., Azzurro E., Bilecenoglu M., Froglia C., Siokou I., Violanti D., Sfriso A., San Martin G., Giangrande A., Katağan T., Ballesteros E., Ramos-Esplá A., Mastrototaro F., Ocaña O., Zingone A., Gambi M.C., Streftaris N. 2010. Alien species in the Mediterranean Sea by 2010. A contribution to the application of European Union's Marine Strategy Framework Directive (MSFD). Part I. Spatial distribution. Mediterranean Marine Science 11 (2): 318-493. DOI: $10.12681 / \mathrm{mms} .87$

Received: 5 July 2013 Accepted: 28 December 2013 Published electronically: 31 March 2014 